\title{
Percepção dos Usuários e Avaliação de Desempenho em Uso de Habitações em Sistemas Construtivos Inovadores
}

\author{
Rosaria Ono \\ Mena Cristina Marcolino Mendes \\ Lucas Melchiori Pereira \\ Sheila Walbe Ornstein \\ Márcio Minto Fabricio \\ Fúlvio Vittorino
}

\section{Introdução}

Este capítulo trata da aplicação de dois instrumentos: o questionário ao morador e o roteiro de entrevista a profissional da assistência técnica, realizados em um empreendimento habitacional de interesse social de unidades familiares isoladas, edificado a partir de um sistema construtivo detentor de Documentação de Avaliação Técnica, de acordo com as Diretrizes de Avaliação Técnica do SiNAT. Os dois instrumentos são parte de um conjunto cujo objetivo é a avaliação de desempenho em uso e manutenção de habitações em sistemas construtivos inovadores. O conjunto de instrumentos proposto, do qual esses dois fazem parte, são detalhados e discutidos em Fabrício; Ono (2015) e Ono et. al. (2015).

A Figura 1 representa um esquema com a contextualização dos dois instrumentos objeto deste capítulo. 
(a)

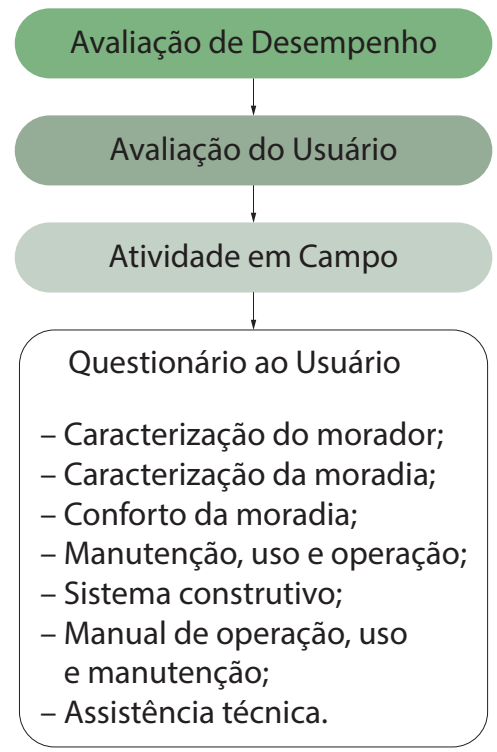

(b)

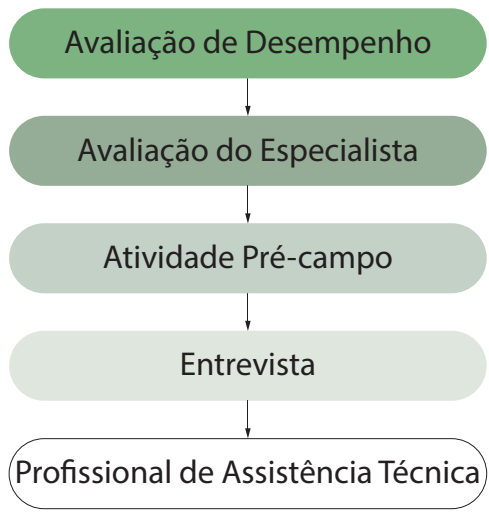

Figura 1. Avaliação de desempenho e instrumentos propostos e aplicados. (a) Questionário ao morador; (b) Entrevista com o profissional de assistência técnica.

\section{Aplicação dos Instrumentos}

\subsection{Aplicação do Questionário aos Moradores}

A aplicação do questionário considerou como população total as 336 unidades habitacionais do empreendimento (Figura 2), localizado em um município de pequeno porte a aproximadamente $350 \mathrm{~km}$ da capital do estado de São Paulo. A partir das informações inicialmente obtidas sobre o empreendimento, entendeu-se que não há características tanto construtivas como do entorno que demandem o uso de técnicas de amostragem probabilística mais elaboradas. Assim, a definição das amostras para aplicação do questionário ao morador foi realizada considerando-se a técnica da amostragem aleatória simples. Para a definiçáo do tamanho dessa amostra, admitiu-se que se encontrariam graus de satisfação e ocorrências sistemáticas (decorrentes de projeto e execução) com alta frequência, da ordem de $80 \%$. Assim, adotando-se um nível de confiança de $90 \%$ e margem de erro de 5\%, obteve-se um tamanho de amostra de, no mínimo, 115 moradores de unidades distintas. 


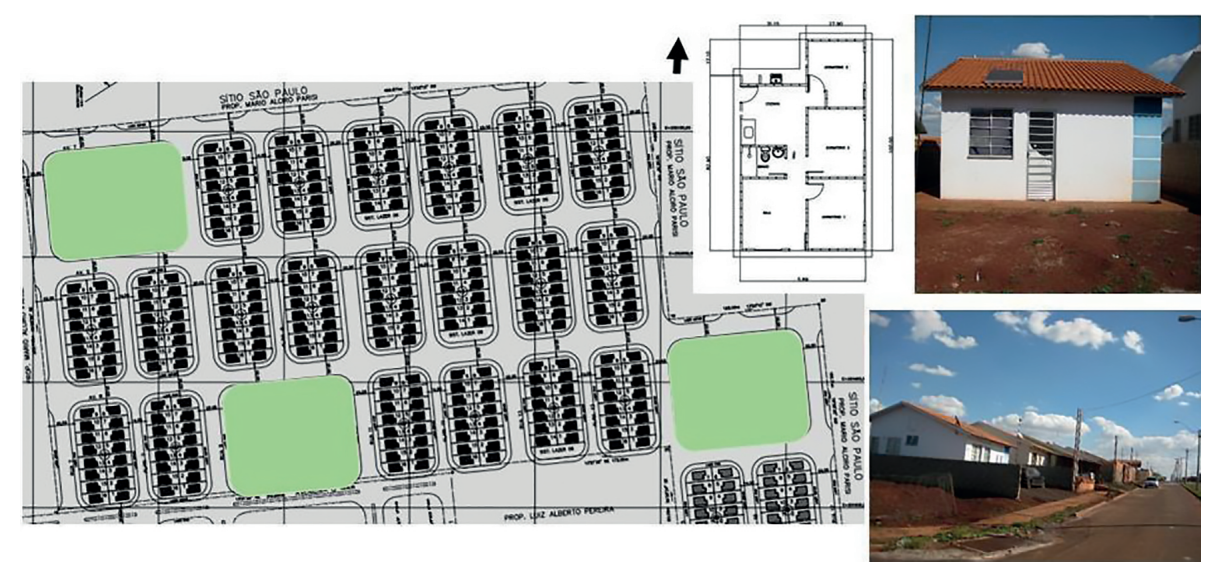

Figura 2. Planta de implantação do empreendimento e da tipologia da unidade habitacional. Fonte: Mapa e planta da unidade habitacional fornecidos pela Construtora (adaptados pelos autores).

Neste estudo, a estratégia para a aplicação do questionário considerou a importância do contato direto com morador/usuário para obter as informaçôes desejadas, pois em trabalhos anteriores (pré-testes) não se obteve a totalidade das respostas, quando os formulários eram entregues nas unidades e recolhidos posteriormente. Também foi testada a coleta de dados por meio do uso de tablets e aplicativo de coleta de dados off-line (ORNSTEIN; ONO; OLIVEIRA, 2017).

O questionário ao morador, elaborado, inicialmente, em formulário físico, foi digitalizado utilizando-se o aplicativo denominado QuickTapSurvey (http://www.quicktapsurvey.com/lg/pt/ versão 6.2.5), instalado em tablets. Esse aplicativo proporcionou algumas vantagens, como a agilização do processo de coleta de dados e a automatização da tabulação desses dados em planilha eletrônica.

A etapa de coleta de dados abrangeu as seguintes fases: (1) elaboração do questionário (online); (2) envio do questionário (online) para o aplicativo instalado nos tablets; (3) coleta de dados propriamente dita no empreendimento (offline) e registro das respostas; (4) envio dos dados coletados (online) e armazenamento no aplicativo; (5) download dos dados coletados e armazenados em planilha eletrônica (online); (6) geração de relatórios e gráficos somente em Portable Document Format (PDF), para visualização (online); (7) tabulação dos dados em planilha eletrônica. 
Uma equipe de quatro pesquisadores realizou a aplicação do questionário junto aos moradores no período de 15 a 17 de janeiro de 2016. Foi possível obter, ao final de três dias de aplicação em campo, respostas de 104 moradores de unidades habitacionais distintas, sorteadas aleatoriamente dentre as 336 unidades do empreendimento. $\mathrm{Na}$ ausência do morador ou em virtude da recusa em participar da pesquisa, procedeu-se um novo sorteio de unidades adicionais. Obteve-se a maior quantidade possível em três dias de trabalho em campo. Antes da aplicação do questionário, foi apresentado ao morador o Termo de Consentimento Livre e Esclarecido (TCLE), aprovado pelo Comitê de Ética (processo CAAE 49362415.1.0000.5390, submetido em 19/09/2015 e aprovado em 27/10/2015), e obtida a assinatura com explícita informação sobre os objetivos e riscos da pesquisa de cada morador entrevistado.

O Quadro 1 apresenta a estrutura do questionário, com os tópicos que o compóem.

Quadro 1. Tópicos do questionário aos moradores.

\begin{tabular}{|c|c|}
\hline Tópicos & Conteúdo \\
\hline $\begin{array}{l}\text { Caracterização do } \\
\text { respondente e do } \\
\text { perfil econômico dos } \\
\text { moradores }\end{array}$ & $\begin{array}{l}\text { Perfil do respondente, idade, gênero, estado civil, grau de } \\
\text { escolaridade, tempo de residência, se proprietário ou inquilino, } \\
\text { tamanho da família, perfil de gastos mensais com necessidades } \\
\text { básicas da moradia (água, energia elétrica, gás, telefonia e } \\
\text { correlatos e condomínio). }\end{array}$ \\
\hline $\begin{array}{l}\text { Caracterização da } \\
\text { moradia atual }\end{array}$ & $\begin{array}{l}\text { Comparação com as condições da moradia anterior, eventuais } \\
\text { alterações realizadas ou previsão de intervenções e desempenho } \\
\text { das instalações prediais. }\end{array}$ \\
\hline Conforto na moradia & $\begin{array}{l}\text { Satisfação com: ergonomia e funcionalidade (dimensões mínimas } \\
\text { dos cômodos), conforto acústico (geradores de ruídos externos } \\
\text { e internos, qualidade da isolação sonora), conforto térmico } \\
\text { (extremos de calor e frio nos diversos ambientes) e conforto } \\
\text { lumínico (eficiência da iluminação natural). }\end{array}$ \\
\hline $\begin{array}{l}\text { Manutenção, uso e } \\
\text { operação }\end{array}$ & $\begin{array}{l}\text { Facilidade de manutenção da moradia: instalações prediais, acaba- } \\
\text { mentos e revestimentos, vedações (parede, piso, teto e cobertura). }\end{array}$ \\
\hline Sistema construtivo & $\begin{array}{l}\text { Conhecimento e opinião sobre o sistema construtivo inovador } \\
\text { empregado. }\end{array}$ \\
\hline $\begin{array}{l}\text { Manual de Operação, } \\
\text { Uso e Manutenção }\end{array}$ & $\begin{array}{l}\text { Recebimento e leitura do manual, nível de compreensão e } \\
\text { qualidade do seu conteúdo. }\end{array}$ \\
\hline Assistência Técnica & $\begin{array}{l}\text { Identificação e forma de resolução de problemas construtivos, } \\
\text { conhecimento sobre o direito à assistência técnica e a avaliação } \\
\text { desse serviço dentro da garantia. }\end{array}$ \\
\hline
\end{tabular}

Fonte: Ono et al. (2015). 
No item "Resultados", a seguir, são apresentadas as análises estatísticas dos resultados da aplicação do questionário.

Além de estatísticas descritivas, foram realizados também testes não paramétricos de dependência do grau de satisfação expresso pelo usuário com suas características socioeconômicas, utilizando-se o teste de aderência do Qui-quadrado.

\subsection{Aplicação do Roteiro de Entrevista com Profissional de Assistência Técnica}

A entrevista com o profissional de assistência técnica trata-se de um roteiro com 10 questóes semiestruturadas. Esse instrumento pré-campo da avaliação do especialista tem a finalidade de balizar as informaçôes obtidas pelos profissionais de assistência técnica prestada pelas construtoras com relação ao desempenho em uso do sistema construtivo. A entrevista foi agendada previamente e realizada em uma hora e vinte minutos.

Uma das recomendaçóes é que essa entrevista ocorra em período anterior à aplicação do "Roteiro de inspeção para avaliação da manutenção da unidade habitacional com sistema construtivo inovador" (Avaliação do especialista - atividade em campo), uma vez que as informaçóes obtidas podem ser úteis na detecção ou identificação de não conformidades na obra. Porém, essa recomendação não foi seguida, tendo em vista a necessidade de aguardar a aprovação pelo Comitê de Ética para a aplicação da entrevista com o profissional de assistência técnica.

Outra recomendação é que, ao realizar a entrevista, o entrevistador não se atenha estritamente ao roteiro, podendo realizar perguntas adicionais e complementares às questóes iniciais, quando achar pertinente.

Em relação ao tratamento dos dados, o entrevistador deve destacar as informaçóes qualitativas mais relevantes obtidas, seguindo o roteiro de entrevista semiestruturada, com base em suas anotaçóes e nas informações registradas.

A entrevista com o profissional de assistência técnica foi realizada no dia 8 de fevereiro de 2017, seguindo o roteiro previamente elaborado, que abrange os seguintes tópicos:

- Processo de prestação de assistência técnica.

- Capacitação da mão de obra para a prestação de assistência técnica. 
- Identificação de necessidade de serviços não planejados.

- Procedimentos necessários para prestação de assistência técnica ao morador/ unidade habitacional/ empreendimento habitacional.

- Sobre o sistema de armazenamento de informações sobre serviços prestados pela assistência técnica (quantidade de ocorrências, identificação de problemas, quantidade de solicitaçôes atendidas).

- Principais reparos realizados nas áreas comuns do condomínio em questấo no último ano.

- Principais reparos realizados nas unidades habitacionais no último ano.

- A qualidade do acesso às instalaçóes, reservatórios e coberturas para realização de manutenção e inspeções.

- O caráter das intervenções de manutenção, se no geral foram preventivas ou corretivas.

- A forma como o usuário/condomínio pode acessar materiais, mão de obra e equipamentos adequados ao sistema construtivo inovador utilizado nas unidades habitacionais em:

- Situaçóes fora da garantia;

- Situações de reforma;

- Melhorias/ampliações na unidade habitacional.

\section{Resultados}

\subsection{Questionário ao Morador}

Do total de unidades do Conjunto Habitacional, 104 unidades foram pesquisadas. Esse número, apesar de ser menor que o originalmente determinado, está próximo dele e gerou margens de erro da mesma ordem de grandeza do que o desejado.

A partir dos horários de início e término de cada entrevista, agrupouse a duração das conversas em 4 classes: até 10 minutos $(16 \%),+10$ até 20 minutos $(60 \%),+20$ a 30 minutos $(18 \%),+30$ até 40 minutos $(6 \%)$ e + 40 até 50 minutos (1\%) (Figura 3). A média de tempo de aplicação (102 dados válidos) foi de 16 minutos. Além da variação inerente ao processo de entrevista, as demais variaçóes se justificam pelo fato de que o questionário foi construído de forma a aprofundar determinados assuntos em função da 
resposta do morador. Assim, por exemplo, quando um respondente afirma que realizou reformas e ampliaçóes na residência, uma série de questóes adicionais é aplicada para detalhar tais eventos. Com base na duração das entrevistas realizadas, é possível estimar o tempo para essa atividade em pesquisas futuras em 20 minutos.

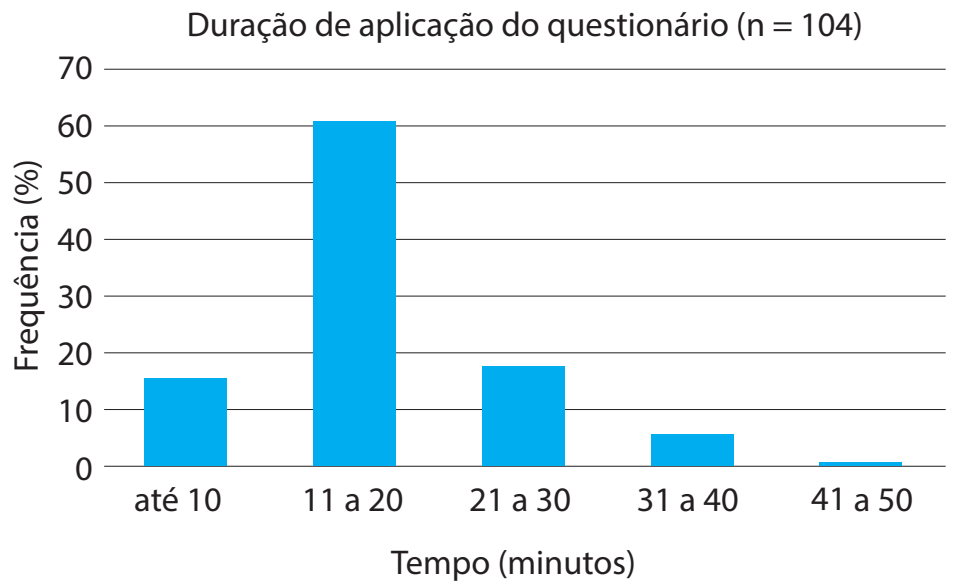

Figura 3. Duração da aplicação do questionário.

As questóes sobre a Caracterizaçáo dos respondentes e perfil dos moradores têm o objetivo de apresentar os dados relativos à idade, gênero, estado civil, escolaridade, residentes por domicílio, gastos mensais, entre outros. Do total de 104 respostas válidas, $77 \%$ dos respondentes declararam ser os responsáveis pela moradia e 23\%, dependentes. A maioria dos respondentes pertence às faixas etárias superiores a 20 anos, sendo a distribuição das idades ilustrada no gráfico abaixo (Figura 4). A grande maioria tem entre 21 e 50 anos de idade (77\%). 


\section{Idade do respondente $(\mathrm{n}=104)$}

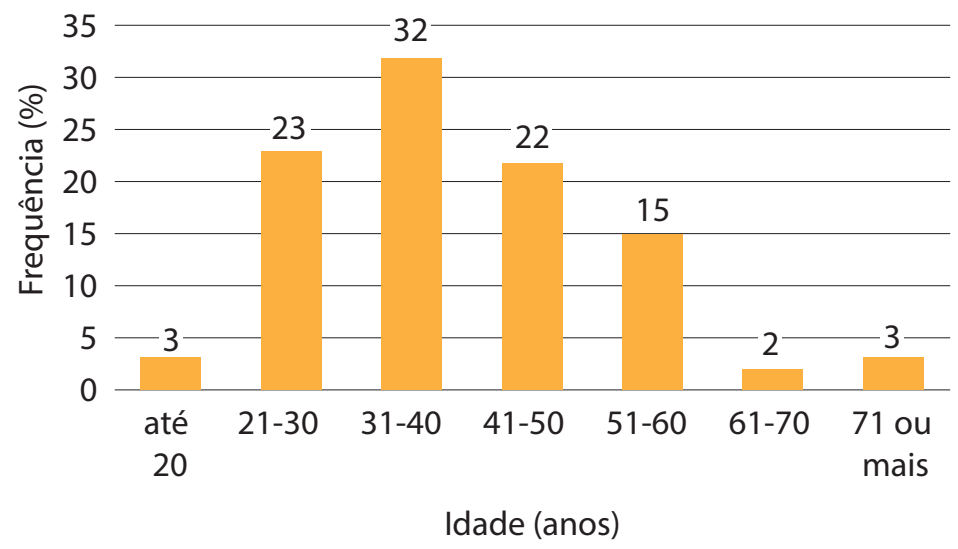

Figura 4. Questionário ao morador - faixa etária dos respondentes.

O gênero dos respondentes é predominantemente feminino (63\%), e a grande maioria dos respondentes declarou ser casado (a) ou possuir união estável (72\%) - Figura 5.

Estado Civil $(\mathrm{n}=104)$

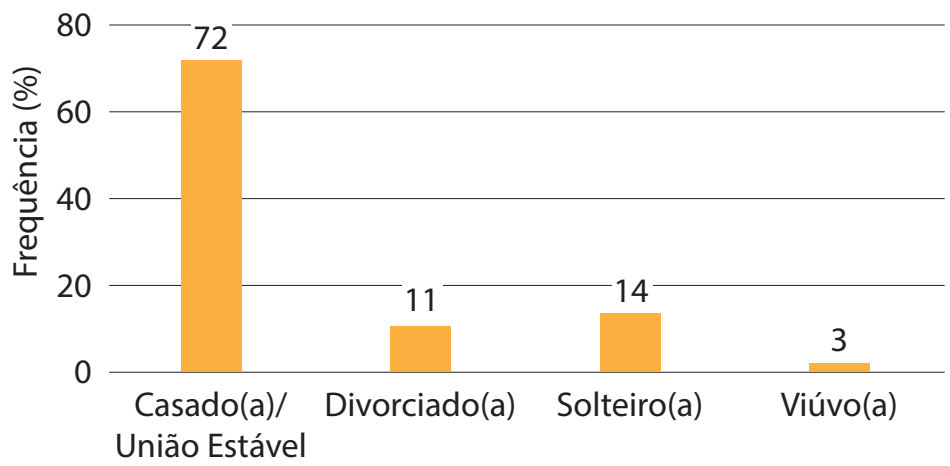

Figura 5. Estado civil do respondente. 
Quanto ao grau de escolaridade, cerca de $40 \%$ dos respondentes declarou ter ensino fundamental completo (11\%) ou incompleto (29\%) e $60 \%$ tem ensino médio completo (32\%) ou incompleto (28\%) (Figura 6).

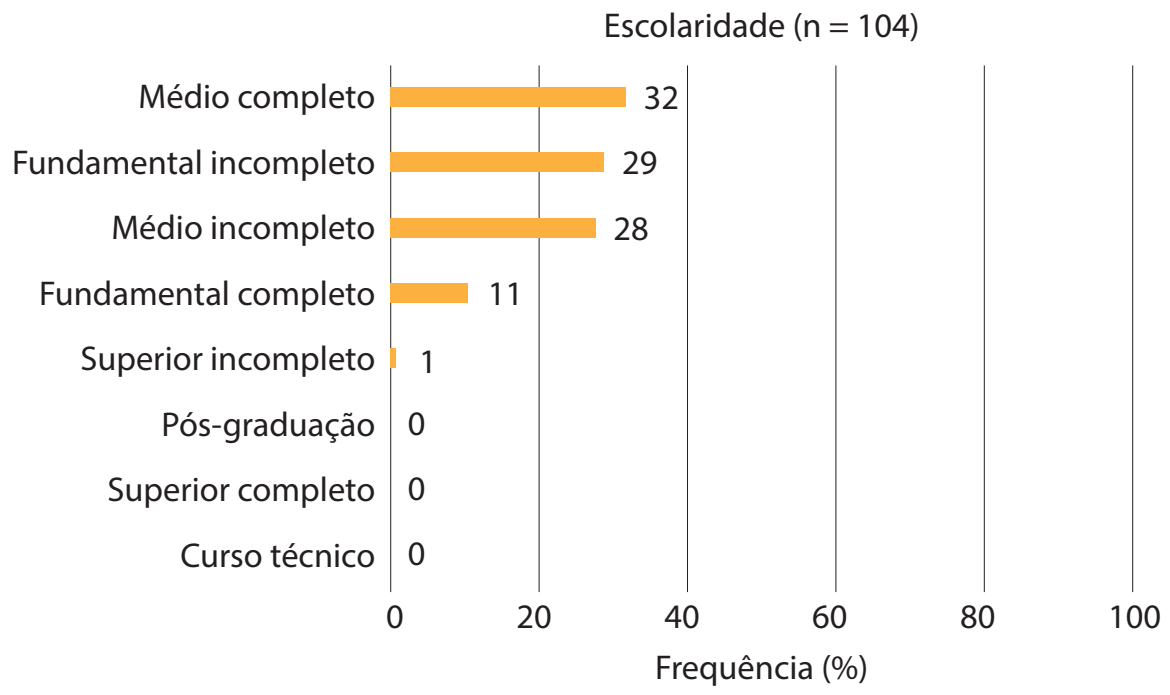

Figura 6. Grau de escolaridade do respondente.

Acerca do tempo de moradia, os participantes informaram residir no conjunto habitacional entre 1 e 2 anos (87\%), isto é, a maioria dos moradores reside no local desde a entrega do empreendimento.

Dos residentes pesquisados, a maioria é proprietária (98\%) e primeiro morador (95\%) do imóvel.

O número total de residentes por unidade domiciliar, incluindo maiores e menores de idade, é de três residentes em 36\% dos casos, quatro residentes em $30 \%$, dois residentes em $18 \%$ e de cinco em $11 \%$ dos casos (vide Figura 7). Portanto, 66\% das unidades apresentam entre três e quatro moradores, sendo que a média de pessoas por unidade da amostra é de 3,5. 
Total de residentes por unidade habitacional $(n=104)$

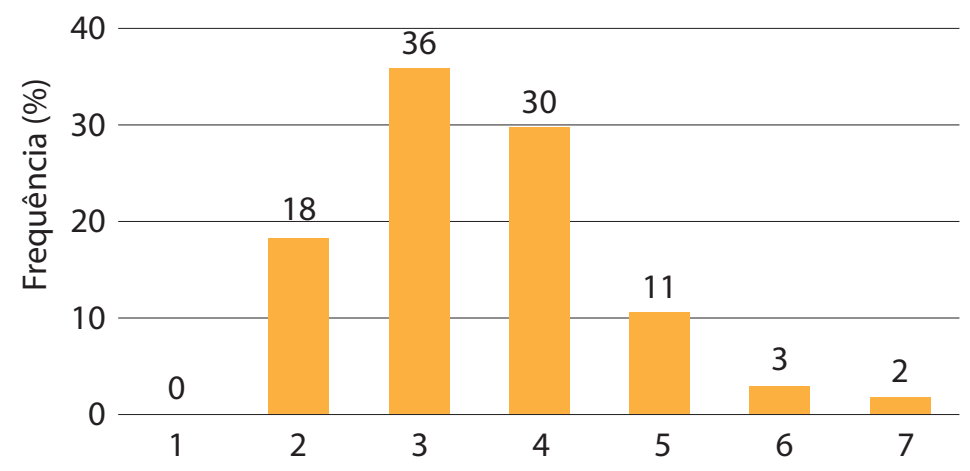

Figura 7. Total de residentes por unidade habitacional.

A constituição das famílias está representada, na maioria, por dois residentes maiores de idade (68\%). A distribuição pode ser vista na Figura 8.

Número de residentes maiores por domícilio $(n=104)$

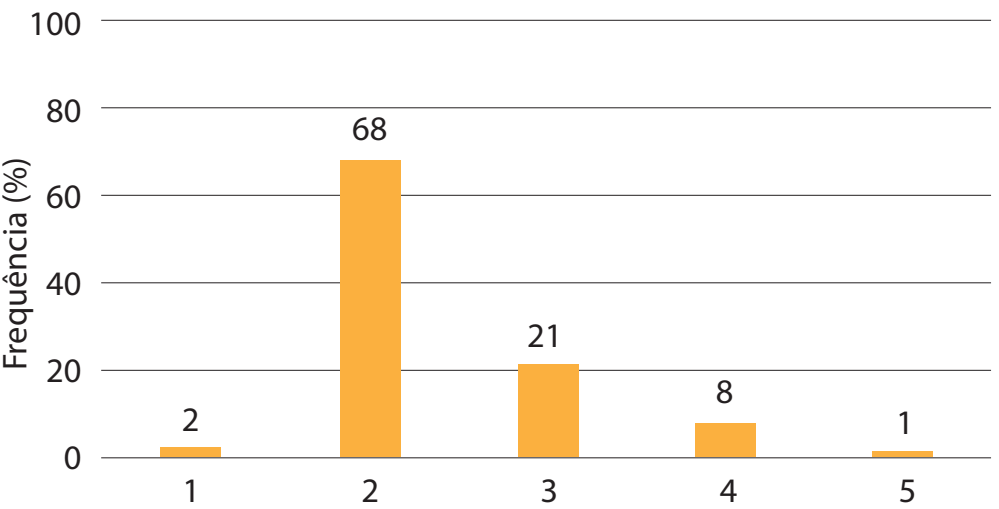

Figura 8. Número de residentes maiores por domicílio.

Uma parte significativa das unidades residenciais pesquisadas (34\%) é composta somente de residentes adultos, ou seja, sem menores. Praticamente $1 / 3$ dos domicílios é composto só de adultos, outro $1 / 3$ tem um menor de idade e $35 \%$ dos domicílios tem 2 ou 3 menores na família (Figura 9). 
Número de residentes menores por domícilio $(n=104)$

100

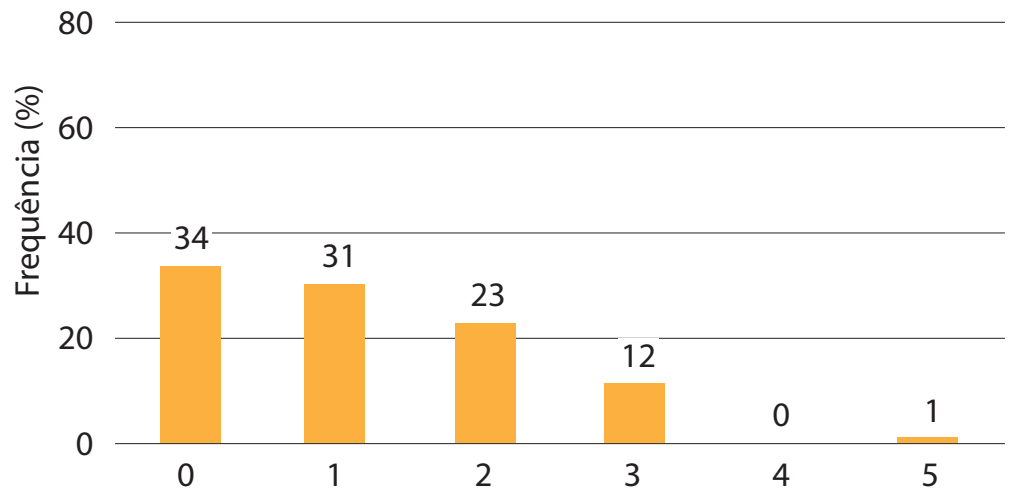

Figura 9. Número de residentes menores por domicílio.

Os gastos mensais por tipo de conta de consumo são apresentados na Figura 10. Os gastos com gás (95\%) e água e esgoto (54\%) são os mais frequentes na faixa de até $\mathrm{R} \$ 50,00$. Já os gastos com energia elétrica (53\%), internet e TV (69\%) são mais frequentes na faixa de $\mathrm{R}$ \$ 51,00 a $\mathrm{R} \$ 100,00$. Há, no entanto, um número considerável de famílias que gastam de $\mathrm{R} \$ 51,00$ a $\mathrm{R} \$ 100,00$ com água e esgoto (37\%), assim como aquelas que gastam de $\mathrm{R} \$ 101,00$ a $\mathrm{R} \$ 200,00$ em energia elétrica (39\%).

As questóes relativas à Caracterizaçáo e condiçóes de uso da moradia têm por objetivo levantar as condiçóes da moradia anterior, eventuais alteraçóes realizadas ou previsão de intervençóes e desempenho das instalaçóes prediais. As frequências de ocorrência apresentadas a seguir são os valores obtidos para a amostra de 104 elementos. As margens de erro a elas associadas correspondem à inferência para a população, formada pelo total de moradias do empreendimento de 336 unidades. Adotou-se o nível de confiança de $95 \%$ para a determinação dessas margens de erro, a fim de se obter intervalos de confiança maiores e, assim, dar-se um caráter mais abrangente às conclusôes. Ressalta-se que, dada a ordem de grandeza das respostas obtidas, todos os valores foram arredondados para números inteiros. Esse procedimento não gerou perda na confiabilidade das conclusôes. 


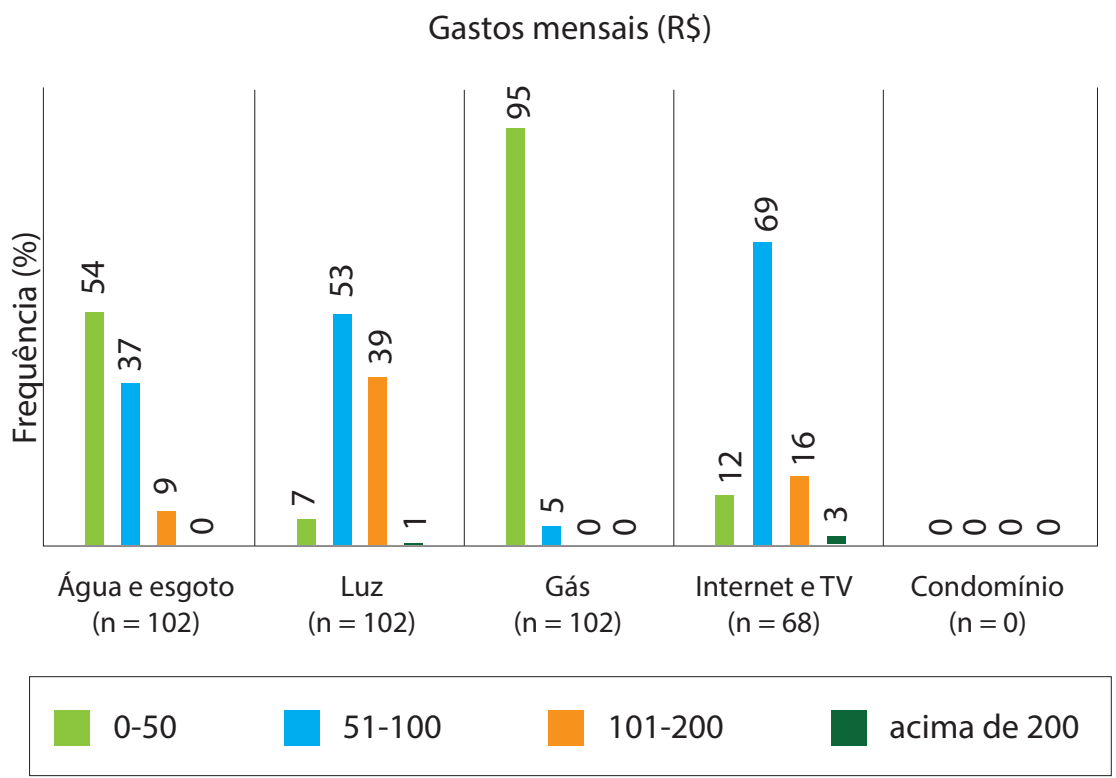

Figura 10. Faixa de gastos mensais dos moradores por tipo de serviço público.

A condiçáo da moradia atual foi considerada "melhor" do que a anterior pela grande maioria dos entrevistados (86\% com margem de erro de $7 \%$ ).

Não houve declaração de ocorrência de acidentes domésticos por parte da maioria dos respondentes ( $94 \%$ com margem de erro de 5\%). Igualmente, a maioria dos respondentes declarou que nunca ocorreu $(98 \%$ com margem de erro de 3\%) um princípio de incêndio em sua moradia.

Relativo às alteraçóes realizadas nas moradias, praticamente metade dos respondentes declarou que "não" realizou modificaçôes nas habitaçóes $(52 \%)$. As alteraçóes realizadas com maior frequência são de construção de garagem para carros e área de lavanderia e de muros. Em valor menor, há obras na cozinha, área de lazer e outras benfeitorias (Figura 11).

Os usuários que declararam ter realizado alteraçóes afirmaram "não" ter encontrado dificuldades na realização da alteração (78\%).

Quanto ao desejo de realizar alteraçóes na moradia, é representativa a resposta "sim" (88\%, margem de erro de 7\%). O desejo mais representativo é de ampliação e construção da garagem, varanda, cozinha e área de serviço. Os desejos de alteraçôes menos representativos são a construção de muros, ampliação de quartos, banheiro, sala, etc. (Figura 12). 


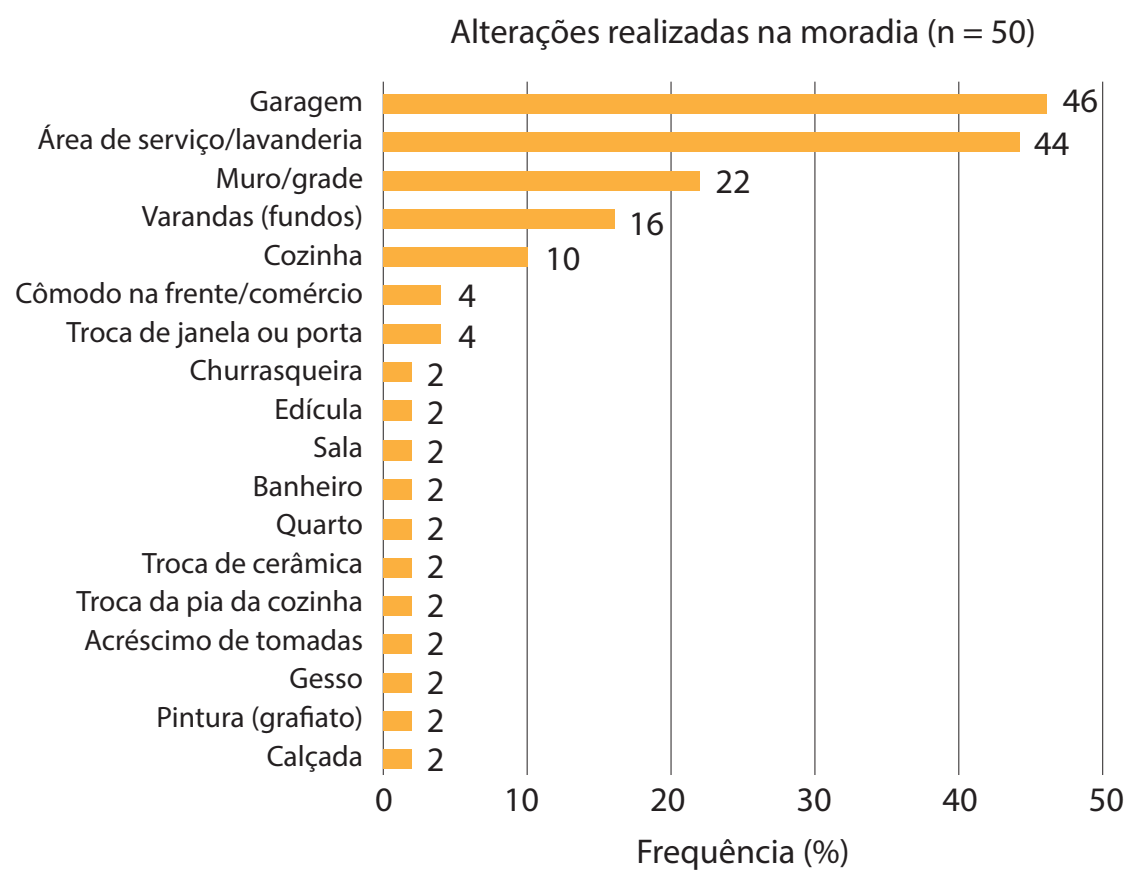

Figura 11. Tipos de alterações realizadas nas moradias.

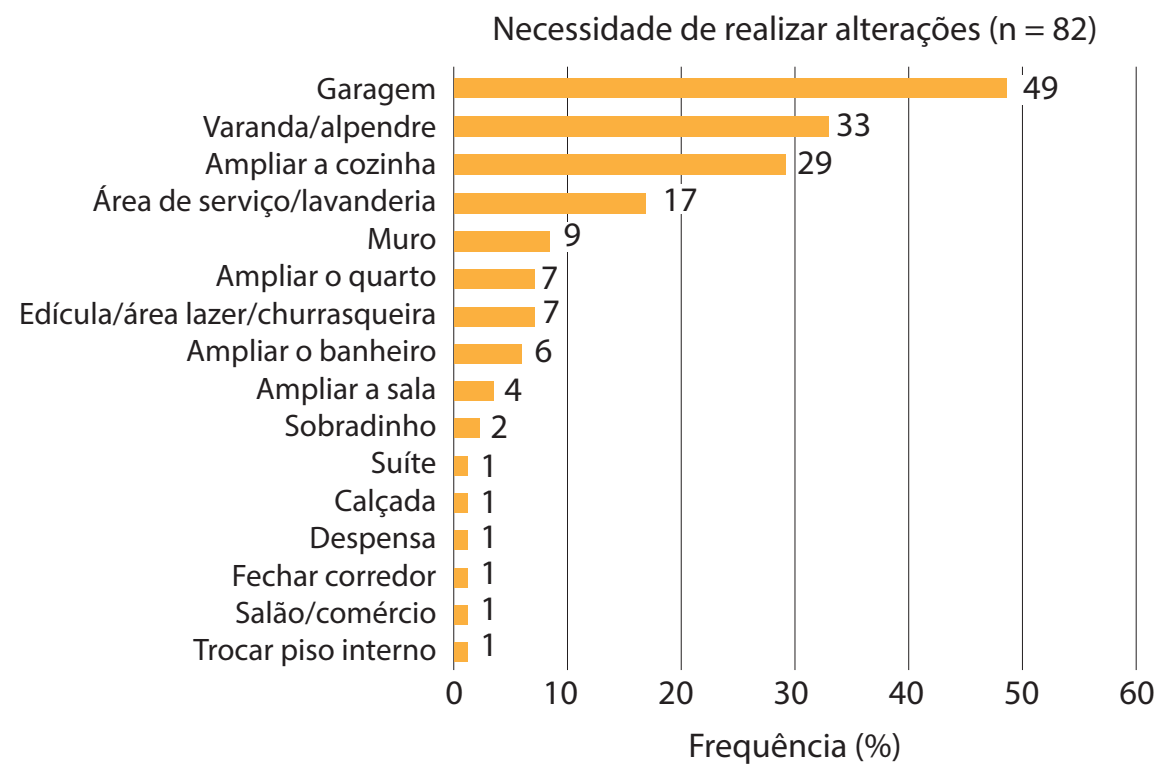

Figura 12. Tipos de alterações necessárias na moradia. 
Os resultados dos respondentes sobre a facilidade de limpeza e funcionamento das instalaçóes (Figura 13) correspondem aos níveis de satisfação obtidos na amostra que contém os itens facilidade de limpeza da moradia, funcionamento das instalaçóes elétricas, funcionamento das instalaçôes hidráulicas e facilidade de pendurar peças suspensas.

\section{Como você avalia a sua moradia?}

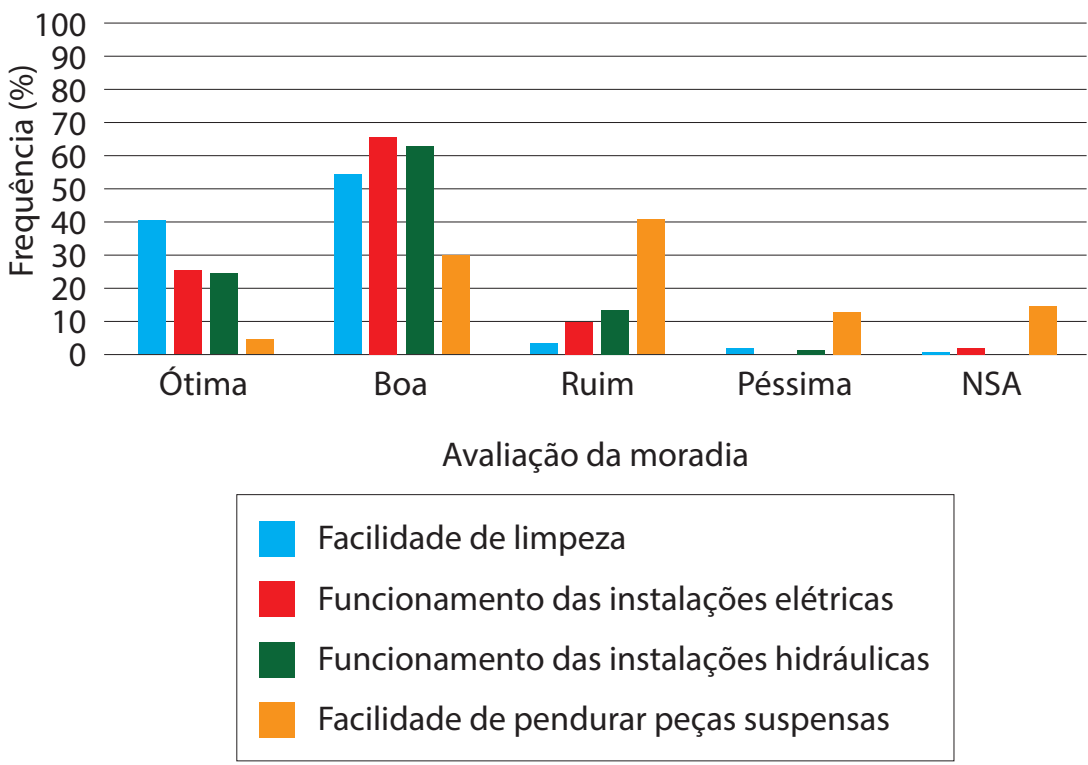

Figura 13. Grau de satisfação dos entrevistados com relação a aspectos de uso e manutenção.

A avaliação da facilidade de limpeza da moradia foi considerada "boa" (53\% com margem de erro 10\%) ou "ótima" (40\% com margem de erro de $10 \%)$. Já a avaliação do funcionamento das instalaçôes elétricas é classificada como "boa" (65\%, margem de erro 9\%) ou "ótima" (25\%, margem de erro $8 \%)$. A avaliação do funcionamento das instalaçôes hidráulicas é avaliada como "boa" (61\%, margem de erro 9\%) ou "ótima" (24\%, margem de erro 8\%).

Por sua vez, a avaliação da facilidade de pendurar peças suspensas é bastante variada: "ótima" (6\%, margem de erro 5\%), "boa" (34\%, margem de erro 10\%), "ruim" (46\%, margem de erro 10\%) ou "péssima" (15\%, margem de erro 7\%). Apesar das margens de erro, a tendência negativa, 
"ruim/péssima" é mais significativa (60\%, margem de erro 10\%) do que a "ótima/boa" (40\%, margem de erro 10\%) (Figura 14).

Facilidade de pendurar peças suspensas $(n=98)$

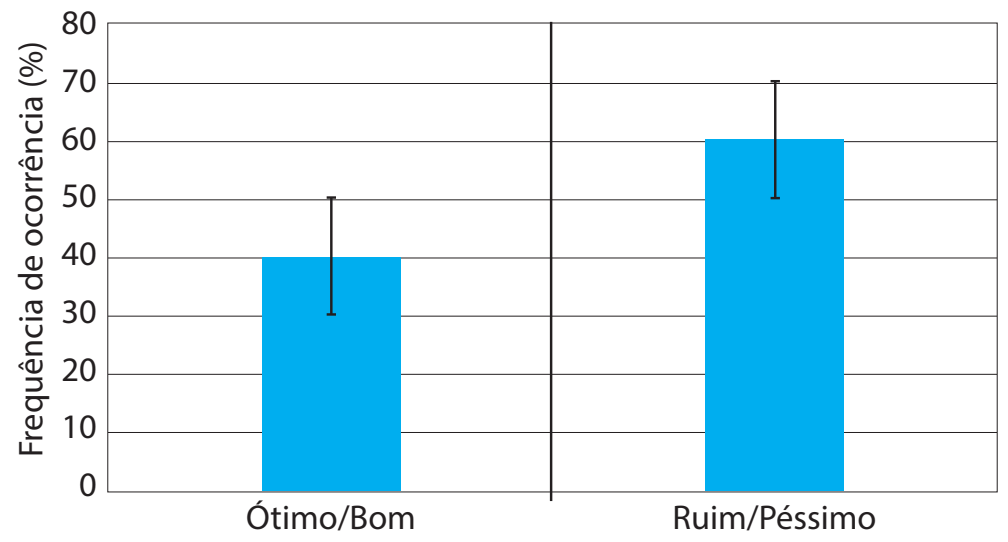

Grau de satisfação

Figura 14. Avaliação da facilidade de pendurar peças suspensas (agrupadas).

O tamanho dos cômodos (sala, dormitórios, banheiro, cozinha e área de serviço) foi avaliado no intuito de se fazer a verificação do conforto da moradia. A Figura 15 apresenta uma visão geral dos níveis de satisfação obtidos na amostra com relação ao tamanho dos cômodos da moradia.

O tamanho da sala é considerado "ótimo" (16\%, margem de erro 7\%) ou "bom" (63\%, margem de erro de 9\%) pela maioria dos respondentes.

O tamanho do dormitório maior também é avaliado positivamente pela maioria dos respondentes, considerado "bom" (67\%, margem de erro $9 \%$ ) ou "ótimo" (15\%, margem de erro 7\%). O mesmo se verifica para o tamanho do banheiro, que foi considerado "bom" (78\%, margem de erro $8 \%$ ) ou "ótimo" (13\%, margem de erro 7\%).

Já sobre o tamanho da cozinha não há um consenso, uma vez que ele foi avaliado negativamente, ou seja, "ruim/péssimo", por 55\% (margem de erro 10\%) dos respondentes e positivamente, "ótimo/bom", por $46 \%$ (margem de erro 10\%). Na Figura 16, pode-se observar os valores obtidos para cada alternativa separadamente e a respectiva margem de erro para a população. Nota-se a expressiva sobreposição nas margens de erro. 


\section{Tamanho dos cômodos}

100

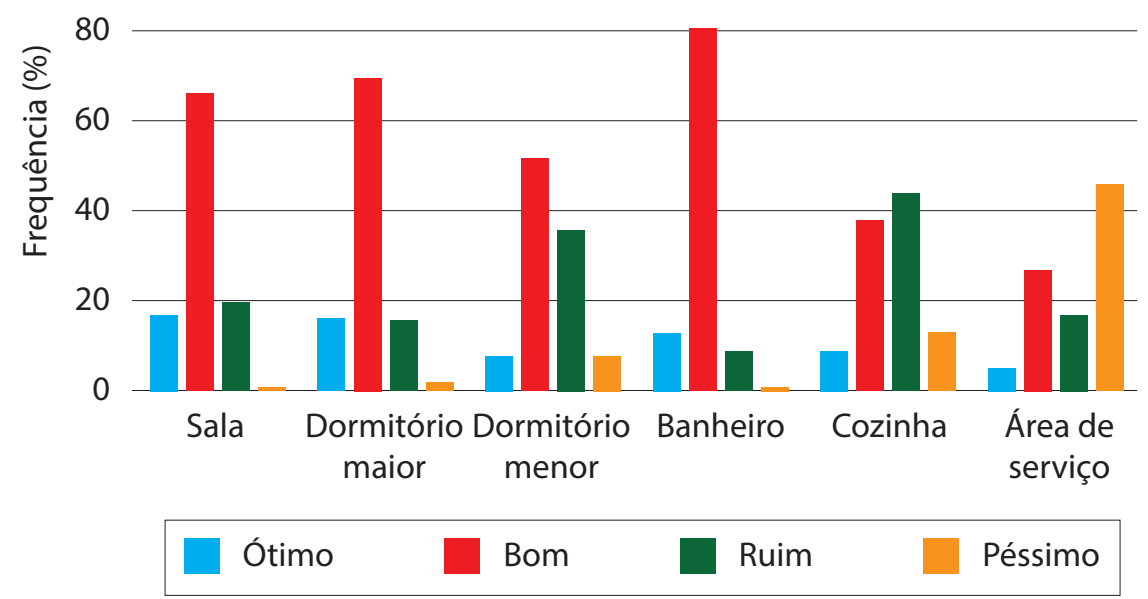

Figura 15. Grau de satisfação dos entrevistados com relação ao tamanho dos cômodos.

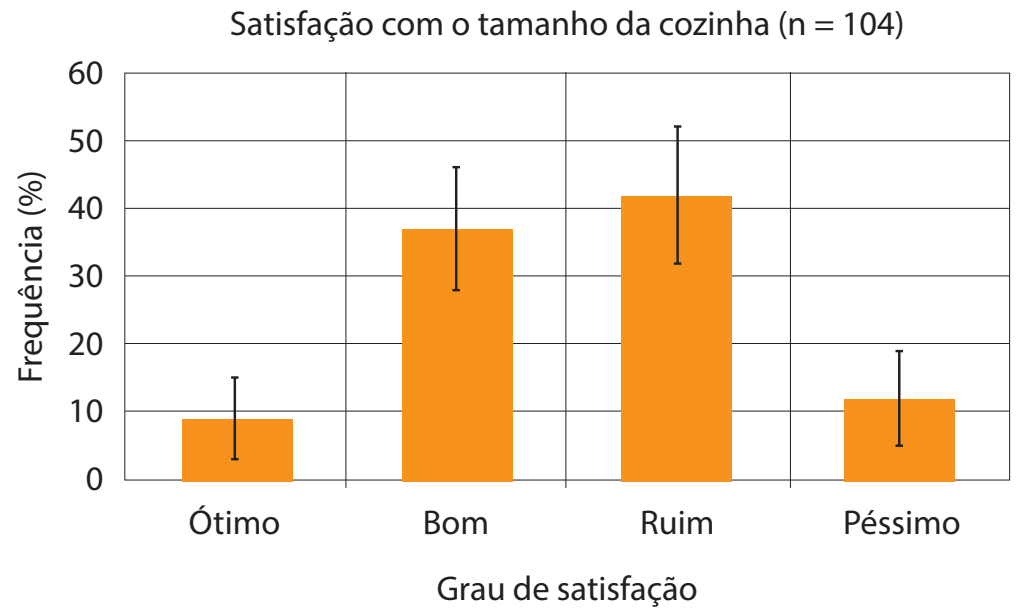

Figura 16. Grau de satisfação com o tamanho da cozinha.

Da mesma forma como foi o obtido para a cozinha, não há um consenso acerca do tamanho do dormitório menor, que foi considerado "ótimo" (8\%, margem de erro 5\%) e "bom" (50\%, margem de erro 9,6\%) por uma pequena maioria dos respondentes. Porém, é significativo o 
número de respondentes insatisfeitos: "ruim" (35\%, margem de erro 9\%) ou "péssimo" (8\%, margem de erro 5\%) (Figura 17).

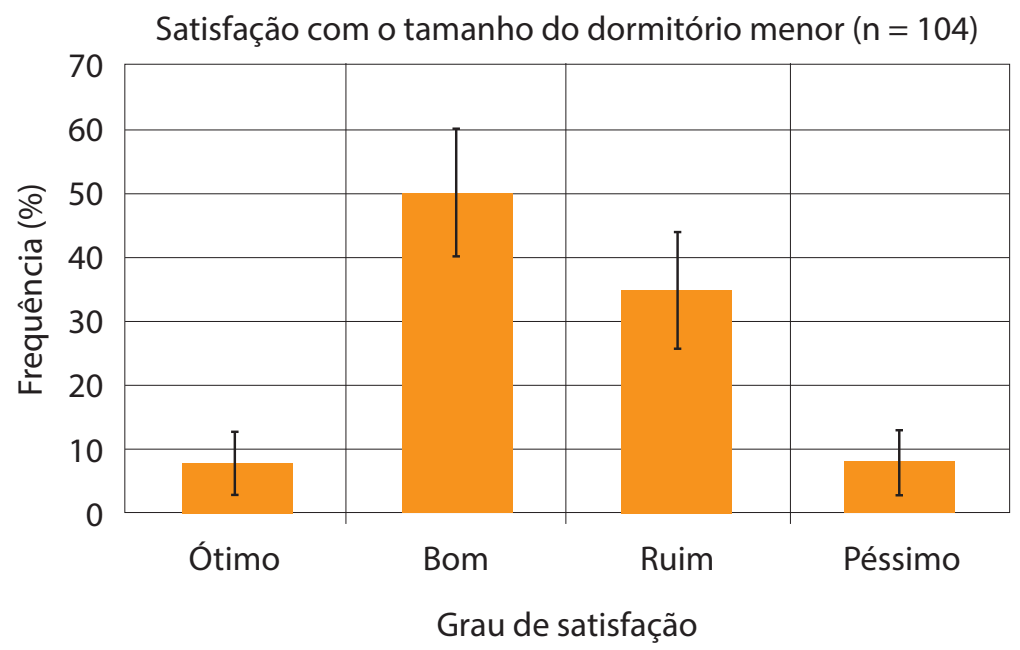

Figura 17. Grau de satisfação com o tamanho do dormitório menor.

O tamanho da área de serviço foi considerado "ótimo" ou "bom" por $34 \%$ (margem de erro 10\%) dos respondentes e "péssima” ou "ruim" por $66 \%$ (margem de erro 10\%). Nesse caso, a avaliaçáo tende a ser claramente negativa (Figura 18).

Satisfação com o tamanho da área de serviço $(n=95)$

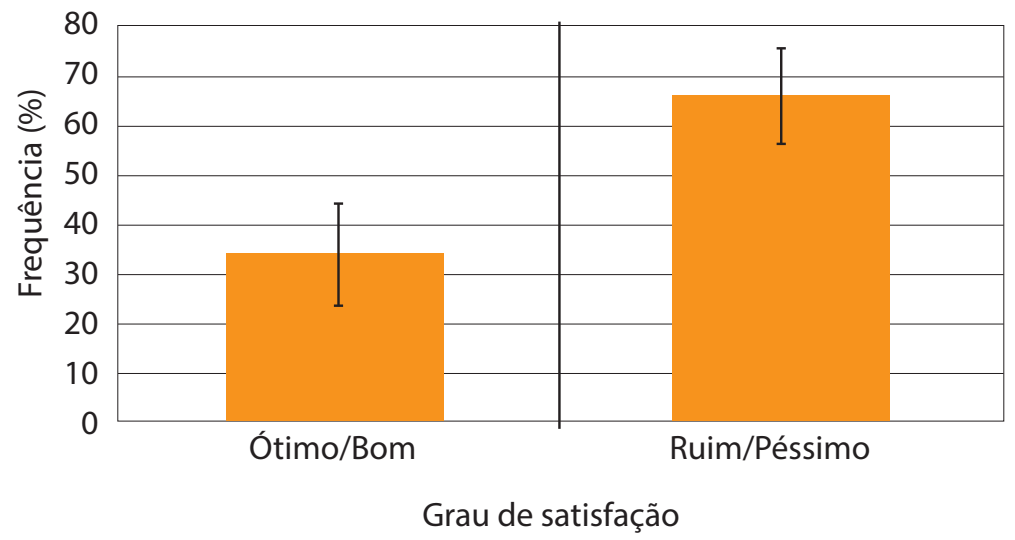

Figura 18. Avaliação do tamanho da área de serviço. 
As questóes relativas à Avaliaçáo do conforto da moradia, além da funcionalidade e do tamanho dos cômodos, contemplam o conforto acústico, conforto lumínico e conforto térmico da edificação.

As questóes de conforto acústico e relativas ao barulho externo e interno foram levantadas junto aos respondentes e revelaram que, tanto os barulhos gerados no interior da casa como os gerados no seu exterior, "não" incomodam a maioria dos entrevistados. Nessa perspectiva, 70\% (margem de erro 9\%) dos entrevistados disseram náo ser perturbados por ruídos provenientes do interior da edificação e 85\% (margem de erro 7\%) dos entrevistados disseram não ser perturbados por ruídos provenientes do exterior da edificação.

Há também alto nível de satisfação dos usuários com relação ao conforto lumínico, uma vez que a grande maioria dos entrevistados afirmou que, durante o dia, "não" é preciso acender lâmpadas para: ler e escrever (86\%, margem de erro 7\%); cozinhar (91\%, margem de erro 6\%); costurar ou realizar outras atividades (97\%, margem de erro $3 \%)$.

Há, ainda, grande satisfação com a sensação de conforto térmico no período frio, visto que a moradia foi considerada "confortável/agradável" pela maioria dos respondentes (71\%, margem de erro 9\%).

Já no período quente, não se verificou uma tendência clara como nos quesitos anteriores, uma vez que a moradia foi considerada "quente" (42\%, margem de erro 10\%) ou "insuportavelmente quente" (17\%, margem de erro $7 \%$ ) pela maioria dos respondentes (60\%) e "confortável/agradável" (21\%, margem de erro $8 \%$ ) ou "levemente quente" $19 \%$, margem de erro $8 \%)$ por cerca de $40 \%$ dos respondentes (Figura 19).

As questóes sobre a Facilidade de manutenção da moradia contemplam os vários subsistemas, como as instalaçóes prediais, acabamentos e revestimentos, vedaçóes (parede, piso, teto e cobertura). A maioria dos respondentes declarou que "não" faz manutenção na casa $(63 \%$, margem de erro $9 \%)$.

As demais perguntas se referiam ao grau de facilidade de manutenção dos vários subsistemas da edificação, dirigidas aos participantes que responderam ter realizado a manutenção. No entanto, com pequena quantidade de respostas positivas, 39\%, não se considerou adequado tentar inferir tais características para uma população maior. 


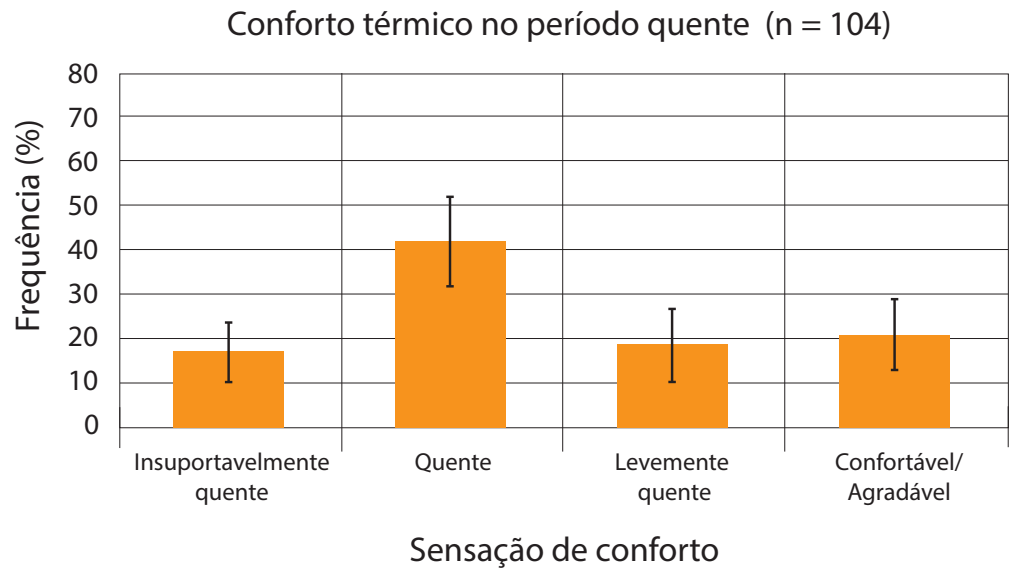

Figura 19. Avaliação do conforto da moradia no período quente.

As questôes sobre o sistema construtivo buscam verificar o conhecimento dos respondentes sobre o sistema construtivo inovador empregado e a opiniāo sobre o uso desse tipo de edificação. Os moradores que responderam que sabem que a casa foi construída com um sistema construtivo diferente (75\%, margem de erro $8 \%$ ) perfazem a maioria e 25\% (margem de erro $8 \%$ ) declararam que não tem essa ciência. A opinião dos moradores a respeito do sistema construtivo é, em sua maioria, positiva, entre "bom" (58\%, margem de erro 11\%) e "ótimo" (28\%, margem de erro 10\%) (Figura 20).

As questóes sobre o Manual de uso, operaçáo e manutençáo pretenderam levantar o recebimento e a leitura do manual, o nível de compreensáo desse material pelos respondentes, a qualidade do seu conteúdo e a capacidade dos respondentes em realizar os procedimentos de manutenção. Os moradores que declararam que receberam o manual de uso, operação e manutenção perfazem 78\% (margem de erro 8\%). Apesar disso, a leitura do manual de operaçáo, uso e manutenção só foi realizada por 33\% do total de 81 respondentes (margem de erro $10 \%$ ) que declararam ter recebido o documento.

A pergunta seguinte, que versava sobre a capacidade de realizar os procedimentos de manutenção descritos no manual, só foi respondida por 27 moradores, número significativamente mais baixo do que os 81 respondentes que declararam ter lido o manual. Portanto, náo se considerou adequado tentar inferir essas características para uma população maior. 


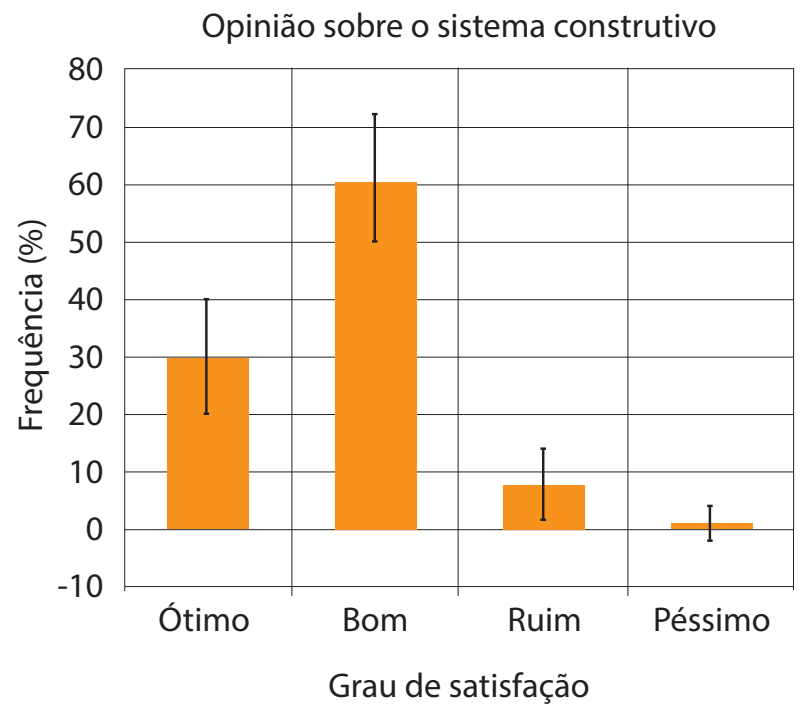

Figura 20. Opinião do morador a respeito do sistema construtivo.

A Avaliação da assistência técnica se deu por meio da Identificação de problemas construtivos, da forma de resolução dessas falhas, sobre o recebimento de assistência técnica e a avaliação desse serviço dentro da garantia pelos respondentes.

A ocorrência dos problemas, representada na Figura 21, mostra, em ordem de frequência, os subsistemas que mais apresentaram problemas na opinião dos respondentes, durante o uso da moradia.

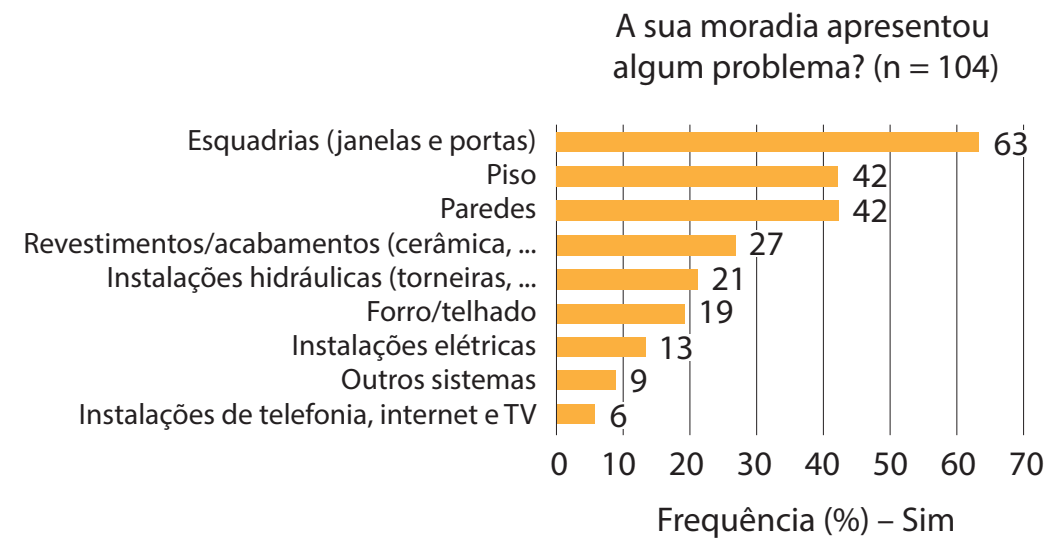

Figura 21. Frequência de problemas apontados na moradia. 
Os problemas apontados com maior frequência pelos moradores entrevistados foram relativos às esquadrias (janelas e portas) com $64 \%$ (margem de erro 9\%).

Outros problemas foram apontados nas paredes e pisos ( $42 \%$, margem de erro $10 \%)$ das casas e nos revestimentos e acabamentos (27\%, margem de erro $9 \%)$.

Em 87 (84\%) das habitaçóes de respondentes, houve pelo menos um problema manifestado em relação à moradia. $\mathrm{Na}$ maioria dos casos, os problemas relatados são de baixa complexidade e de simples resolução.

Seguem tabelas com as frequências das citaçôes dos problemas, classificados por partes do sistema construtivo, considerando, além das respostas às perguntas específicas, o agrupamento e reclassificação das respostas abertas.

Os problemas em portas e janelas devido à falta de estanqueidade, em geral, pela entrada de água de chuva, foram encontrados com frequência de $50 \%$ nas respostas dos entrevistados. Outro problema recorrente das janelas foi o do emperramento das folhas. Outras reclamaçóes aparecem com menor frequência de ocorrência, conforme pode ser visto na Tabela 1 .

Tabela 1. Problemas encontrados em Portas/Janelas.

\begin{tabular}{lcc}
\hline \multicolumn{1}{c}{ Problemas encontrados } & $\begin{array}{c}\text { Número de } \\
\text { Citações }\end{array}$ & $\begin{array}{c}\text { Citações / Total } \\
\text { de Unidades }\end{array}$ \\
\hline $\begin{array}{l}\text { Entrada de água/Falta estanqueidade à água / } \\
\text { Entra água pela porta }\end{array}$ & 52 & $50 \%$ \\
\hline Emperramento de folha - Janela & 11 & $11 \%$ \\
\hline Barulhenta/Com Trepidação/Estralam - Janela & 5 & $5 \%$ \\
\hline Fechadura de má qualidade/Acessório Frágil/ & 4 & $4 \%$ \\
Trava não funciona & 4 & $4 \%$ \\
\hline Frágil/Quebras/Peça Quebrada/Vidro Frágil & 2 & $2 \%$ \\
\hline Não Escurecem o Ambiente & 1 & $1 \%$ \\
\hline Entra Vento/Falta estanqueidade ao ar & 1 & $1 \%$ \\
\hline Vidros soltaram & 1 & $1 \%$ \\
\hline Porta da cozinha cedeu & & \\
\hline
\end{tabular}

A maior frequência de ocorrência de reclamaçóes sobre o piso (Tabela 2) está relacionada à qualidade da placa utilizada, uma vez que os moradores apontaram problemas típicos de durabilidade da superfície, como manchas e desgastes e poucas reclamaçóes com relação ao processo de execução, como aderência ou desnível. 
Tabela 2. Problemas encontrados em Pisos.

\begin{tabular}{lcc}
\hline \multicolumn{1}{c}{ Problemas encontrados } & $\begin{array}{c}\text { Número de } \\
\text { Citações }\end{array}$ & $\begin{array}{c}\text { Citações / Total de } \\
\text { Unidades }\end{array}$ \\
\hline $\begin{array}{l}\text { Placas de “Má Qualidade”: Manchas/Desgaste/ } \\
\text { Descascado }\end{array}$ & 27 & $26 \%$ \\
\hline Placa Solta/Som Oco/Afundamento & 8 & $8 \%$ \\
\hline $\begin{array}{l}\text { Desnível/Acúmulo de Água/ Acúmulo de } \\
\text { Água na Calçada }\end{array}$ & 7 & $7 \%$ \\
\hline Infiltração/Umidade & 5 & $5 \%$ \\
\hline Rejunte Soltando & 3 & $3 \%$ \\
\hline
\end{tabular}

As reclamações referentes às paredes (Tabela 3) estão eminentemente relacionadas à presença de umidade e bolor em sua superfície, além de trincas e fissuras.

Tabela 3. Problemas encontrados em Paredes.

\begin{tabular}{lcc}
\hline Problemas encontrados & $\begin{array}{c}\text { Número de } \\
\text { Citações }\end{array}$ & $\begin{array}{c}\text { Citações / Total de } \\
\text { Unidades }\end{array}$ \\
\hline Bolor/Umidade/Mofo/Infiltração & 36 & $35 \%$ \\
\hline Trinca/Rachadura/Fissura & 10 & $10 \%$ \\
\hline Descascado/Soltou Reboco & 2 & $2 \%$ \\
\hline
\end{tabular}

As ocorrências de reclamações em instalações hidráulicas (Tabela 4) são menores do que nos demais tópicos apresentados acima, estando associadas eminentemente à qualidade dos componentes e não a falhas sistêmicas propriamente ditas.

Tabela 4. Problemas encontrados em Instalações Hidráulicas.

\begin{tabular}{lcc}
\hline \multicolumn{1}{c}{ Problemas encontrados } & $\begin{array}{c}\text { Número de } \\
\text { Citações }\end{array}$ & $\begin{array}{c}\text { Citações / Total de } \\
\text { Unidades }\end{array}$ \\
\hline $\begin{array}{l}\text { Vazamentos: chuveiro, caixa d'água, tanque, torneira } \\
\text { da cozinha e local não especificado }\end{array}$ & 13 & $13 \%$ \\
\hline $\begin{array}{l}\text { Defeitos em componentes: Registro, torneira do } \\
\text { tanque, registro do boiler, vaso sanitário e não } \\
\text { especificado }\end{array}$ & 9 & $9 \%$ \\
\hline $\begin{array}{l}\text { Sistema de aquecimento de água: Chuveiro, } \\
\text { aquecedor }\end{array}$ & 3 & $3 \%$ \\
\hline Barulho & 1 & $1 \%$ \\
\hline Pouca vazão de água no chuveiro & 1 & $1 \%$ \\
\hline
\end{tabular}


Os problemas mais citados em forro/telhado foram as goteiras, que tanto podem ser decorrentes de quebra de telhas como de falhas de execuçáo da cobertura, conforme pode ser visto na Tabela 5 .

Tabela 5. Problemas encontrados em Forro/Telhado.

\begin{tabular}{lcc}
\hline Problemas encontrados & $\begin{array}{c}\text { Número de } \\
\text { Citações }\end{array}$ & $\begin{array}{c}\text { Citações / Total de } \\
\text { Unidades }\end{array}$ \\
\hline Goteira & 15 & $14 \%$ \\
\hline Telha Quebrada & 5 & $5 \%$ \\
\hline Bolor & 1 & $1 \%$ \\
\hline Trinca no Forro & 1 & $1 \%$ \\
\hline
\end{tabular}

Os problemas citados nas demais instalaçôes também apresentam baixa ocorrência (Tabela 6), destacando-se apenas a queda frequente de disjuntores $(8,7 \%)$, cuja origem não pode ser determinada sem uma análise mais aprofundada.

Tabela 6. Problemas encontrados em Instalações Elétricas, Telefonia, Internet e TV.

\begin{tabular}{lcc}
\hline \multicolumn{1}{c}{ Problemas encontrados } & $\begin{array}{c}\text { Número de } \\
\text { Citações }\end{array}$ & $\begin{array}{c}\text { Citações / Total de } \\
\text { Unidades }\end{array}$ \\
\hline Queda frequente de disjuntores & 9 & $9 \%$ \\
\hline $\begin{array}{l}\text { Curtos-circuitos: em geral e especificado no poste de } \\
\text { entrada }\end{array}$ & 3 & $3 \%$ \\
\hline Dificuldades em passar cabeamento & 3 & $3 \%$ \\
\hline Falta padrão na fiação & 1 & $1 \%$ \\
\hline Não tinha fio terra & 1 & $1 \%$ \\
\hline Desloca a caixa da tomada & 1 & $1 \%$ \\
\hline Outras & 2 & $2 \%$ \\
\hline
\end{tabular}

Ainda sobre a avaliação da assistência técnica, foi realizada uma análise do serviço, quanto ao acionamento desse serviço pelos moradores. A grande maioria dos respondentes declarou que "não" acionou o serviço (80\%, margem de erro $8 \%$ ), contra $20 \%$ (margem de erro $8 \%$ ) que o fizeram.

Dos 21 respondentes que acionaram a assistência técnica, a maioria classifica o atendimento como "péssimo" (57\%) ou "ruim" (14\%). Somente $28 \%$ avaliaram o serviço positivamente: como "ótimo" (14\%) ou "bom” (14\%) (Figura 22). Dos usuários que classificam o atendimento como 
péssimo, a maioria das respostas (38\%) está relacionada à qualidade do atendimento no geral. Das demais classificações, a opção "péssima” está relacionada ao tempo para responder a solicitação do serviço (5\%), tempo para a realização do serviço $(5 \%)$, qualidade do material utilizado $(5 \%)$ e outros $(5 \%)$.

Como você classifica o atendimento da assistência técnica? $(n=21)$

100

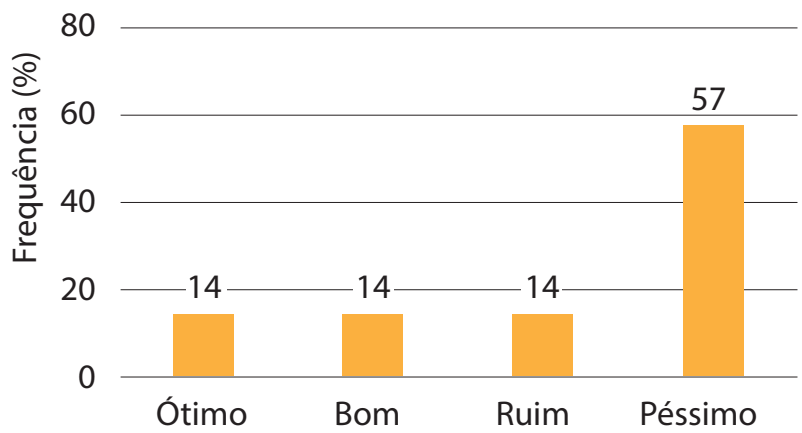

Figura 22. Qualidade do atendimento da assistência técnica.

Seja qual for o motivo, observa-se que os moradores buscam a solução dos problemas patológicos em suas moradias independentemente do acionamento da assistência técnica. Dos moradores entrevistados que declararam haver problemas em suas moradias, $48 \%$ tiveram os seus problemas resolvidos. Nessas moradias, os problemas foram resolvidos pelo próprio "usuário" em 69\% dos casos, pela construtora/assistência técnica em $14 \%$ e por outros intervenientes em $17 \%$ dos casos, conforme pode ser visto na Figura 23. 
Os problemas apresentados foram resolvidos por quem? $(n=42)$

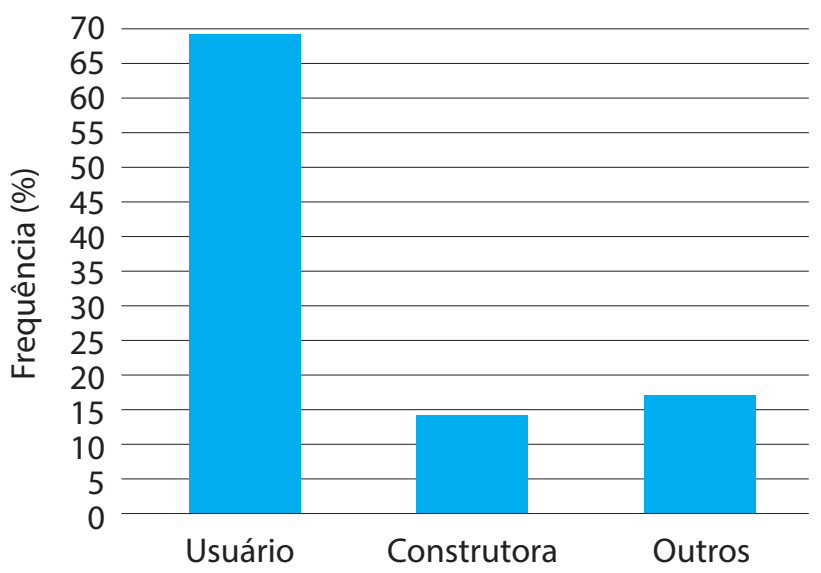

Figura 23. Agentes que resolveram os problemas.

\subsubsection{Análise Cruzada das Respostas dos Moradores}

A partir da análise cruzada das respostas dos moradores envolvendo o gênero, grau de escolaridade ou faixa etária, foi possível constatar que: não há dependência entre grau de satisfação dos respondentes com a moradia e o gênero do respondente; não há também relação de satisfação com grau de escolaridade ou faixa etária.

Foi encontrada dependência entre sexo do respondente e facilidade de instalar peças suspensas. Nesse item, 54\% dos homens respondentes declararam a opção "boa" ou "ótima” e 70\% das mulheres declararam "ruim ou péssima”.

A análise cruzada das respostas no que diz respeito à manifestaçáo de desejo e realização de intervençáo na casa geraram resultados significativos quanto à essa relação. Dos 104 respondentes, 21 não planejam fazer intervenção na unidade ou no lote. Dentre esses 21 respondentes, 15 já fizeram alguma intervenção e apenas 6 não fizeram e não pretendem fazer qualquer tipo de intervenção. Dos que pretendem fazer alguma intervenção, apenas 7 declararam o desejo de intervir nos dormitórios. As demais intervenções dizem respeito à construção de garagem $(36 \mathrm{com}$ desejo de realizar e 24 já realizadas). Foram também relatados 22 planos de 
intervenção na cozinha e 5 intervençóes já realizadas nesse ambiente. Outros 48 respondentes declararam o desejo de construir uma cobertura (varanda) para a área de serviço e/ou atividades de lazer e 32 já o fizeram.

Intervenções em componentes como pias, tomadas, revestimentos, portas e janelas (elementos não estruturais) aparecem em 9 casos, já realizados, e 2 casos de desejo de troca de revestimento de piso.

Dos respondentes, 4 planejam ampliar área construída com edificação adicional (edícula ou sobrado) e outros 4 , construir um banheiro adicional. Além disso, 4 respondentes já construíram uma edificação ou cômodo adicional.

Muros já foram construídos por 7 respondentes e grades foram instaladas por mais 2. Outros 7 declararam pretender construir muros.

Foi possível obter como resultado a relaçáo entre o recebimento do Manual, a leitura e o conhecimento do sistema construtivo por parte dos respondentes. Dos 104 respondentes, 81 declararam que receberam o Manual de Uso, Operação e Manutenção da residência. Destes, apenas 27 responderam que leram o referido Manual.

Do total de 102 respondentes, 77 afirmaram saber que o sistema é diferente, dentre os quais somente 24 leram o Manual. Assim, grande parte dos residentes sabiam do sistema diferente, mesmo sem a leitura do Manual.

\subsection{Entrevista com o Profissional de Assistência Técnica}

A entrevista foi realizada com o profissional de assistência técnica por videoconferência e teve duração de uma hora e vinte minutos. Na sequência da entrevista, o profissional encaminhou o Termo de Consentimento Livre e Esclarecido (TCLE) assinado digitalmente, conforme exigência do Comitê de Ética em Pesquisa.

A primeira parte da entrevista diz respeito ao empreendimento: nome, local, data de entrega e tipo de sistema construtivo. A segunda parte corresponde às funçôes desempenhadas e tempo de experiência do profissional. A terceira parte, por sua vez, é reservada para as questóes sobre o processo de assistência técnica, a capacitação da mão de obra, a execução de serviços não planejados, os procedimentos necessários à prestação do serviço, o armazenamento das informaçóes sobre os serviços realizados, os 
reparos das áreas comuns, os reparos das unidades habitacionais, a qualidade do acesso às instalaçóes, reservatórios e coberturas para as manutençôes, se as manutençóes foram preventivas ou corretivas.

A seguir, segue o resumo da entrevista:

O profissional entrevistado informou ser o responsável da construtora pela assistência técnica, trabalha na empresa há 10 anos e já exerceu várias funçôes, tais como: gestão de obras, fiscalização da execução e aprovação de projetos perante prefeituras municipais e a CDHU, no caso de sistemas alternativos.

Sobre o processo de prestação da assistência técnica, o profissional informou que a ação se inicia com o contato do mutuário com a assistente social da prefeitura (setor de serviço social e de engenharia). Se as falhas se tratassem de serviços de infraestrutura (postes, hidrômetro e muros, por exemplo), a responsabilidade pela assistência técnica era da prefeitura. A responsabilidade da construtora se restringia a aspectos construtivos da unidade familiar. Nesse último caso, o responsável, ao identificar o problema, marcava a visita de reparo /manutenção (sempre às quintas e sextas-feiras), e, em dois dias, realizava-se o serviço. Quando o morador estava impossibilitado de acompanhar o serviço dentro da residência, ele deixava a chave com o vizinho e o serviço era acompanhado pela assistente social da prefeitura. Quando o serviço era externo, não havia a necessidade de acompanhamento da prefeitura. Não houve a participação da Companhia de Desenvolvimento Habitacional e Urbano (CDHU) na manutenção, que foi responsável somente por fiscalizar a execução das casas. Os serviços de assistência técnica eram realizados por funcionários da empresa (paredes e estrutura) ou de subempreiteiras (instalaçóes) que fizeram a parte das ligaçóes hidráulicas, elétricas, pintura e cobertura. Para os serviços de pintura, por exemplo, foram contratadas quatro empresas. Assim, um contrato de prestação de serviços que previa a retenção de 3\% a 5\% do valor do serviço contratado era realizado com as empresas subcontratadas, para garantir a realização dos serviços de reparos pós-obra em caso de manutenção.

O profissional mencionou que a mão de obra para a assistência recebia capacitação e treinamento da empresa, mas não havia mão de obra específica para a assistência técnica, a qual era feita pela mesma equipe que executou a obra. Os profissionais são os mesmos e receberam treinamento da empresa para atender o Programa da Qualidade da Construção Habitacional 
do Estado de São Paulo (QUALIHAB). Dentro da fábrica de painéis, é fornecido o treinamento para os funcionários (separados por serviços, como fôrma, armação, concretagem, revestimento e tubulações). Para os funcionários do transporte e montagem (solda, por exemplo), o treinamento era realizado no canteiro de obra. Os profissionais subcontratados receberam o treinamento no início do processo de construçáo, quando houve a contratação dos serviços das empresas terceirizadas.

Para a realização das atividades de assistência técnica, inicialmente identificam-se as necessidades dos serviços a partir do planejamento prévio, após a vistoria e identificação do problema, antes do deslocamento do profissional ao local. Tanto no caso de serviços planejados como não planejados, são seguidas as orientaçóes do QUALIHAB para a aquisição de materiais e a lista de fornecedores de serviços e produtos qualificados da CDHU. A identificação de serviço não planejado ocorre no local, pelo profissional técnico, tal como a necessidade de um profissional do serviço hidráulico para executar um reparo na junção ou ligação, verificando se será preciso "abrir a parede". Nesse caso, é necessário agendar o serviço do pedreiro, inicialmente, e do profissional da hidráulica, posteriormente, para realizar o serviço do reparo hidráulico. Como etapa do processo de qualidade, após a montagem da $1^{\text {a }}$ unidade, foi realizada uma avaliação crítica sobre os resultados obtidos, a fim de verificar as compatibilidades de hidráulica, elétrica, vãos das esquadrias, etc.

Os procedimentos para a prestaçáo da assistência técnica ocorreram somente durante a vigência do período de garantia do empreendimento. A inspeção e o serviço eram agendados junto à prefeitura que fazia o cadastro do solicitante. $\mathrm{O}$ serviço de assistência técnica não era realizado quando havia falhas no registro das informaçóes sobre a unidade habitacional que gerou a ocorrência. A CDHU foi responsável pela fiscalização da construção realizada pelas empresas construtoras e pela prefeitura. $\mathrm{O}$ seguro que consta no contrato do morador com a CDHU é para resolver problemas, desde que dentro do prazo de garantia e cumprido os requisitos básicos, como a não realização de alteraçóes na casa.

As informaçóes referentes à realizaçáo dos serviços de assistência técnica prestados eram registradas em planilhas. Registravam-se e controlavam-se os serviços realizados e os não realizados; anotavam-se o motivo, como o caso de moradores que resolviam o problema por conta ou 
os não encontrados no endereço informado. A prefeitura era comunicada dos serviços realizados ou não.

Os principais reparos que ocorreram foram a interligação entre o hidrômetro e a casa. No interior das unidades habitacionais, os principais reparos foram realizados nas instalaçôes hidráulicas. Foram realizadas substituições em joelhos azuis rachados; reparos em paredes de banheiros e de tanques com colocação de fita firlon (veda rosca) em pontos nos quais elas eram ausentes e que geraram infiltração de água, além de substituição de vasos sanitários.

A qualidade do acesso às instalaçóes para manutençáo, como caixa d'água e cobertura, foi considerada adequada. $O$ projeto elaborado pela CDHU prevê o acesso à caixa d'água. Quanto ao acesso aos materiais, mão de obra e equipamentos para manutenção das unidades habitacionais para situaçôes fora da garantia, o morador deve consultar o manual. Nada é diferente do sistema convencional, tudo pode ser encontrado no mercado de construção. Não há fornecedores específicos porque a técnica é convencional. A parede é entregue pronta com as instalaçóes embutidas - obras podem ser realizadas com materiais e mão de obra convencionais. Para situaçôes de reforma, também se recomenda consultar o manual, em que constam as informaçóes necessárias. As melhorias e ampliaçóes na unidade habitacional devem observar o que consta no manual, podendo ser realizadas com sistema convencional.

\subsection{Cruzamento das Informações do Questionário ao Morador com a Entrevista com o Profissional de Assistência Técnica}

A partir dos resultados dos questionários aos moradores foi possível realizar um cruzamento com as informaçóes do profissional de assistência técnica, como as alteraçôes e os reparos realizados, o funcionamento das instalações hidráulicas e os reparos da assistência técnica, manutenção da casa e conhecimento sobre o serviço de assistência técnica e problemas nos principais subsistemas com os problemas resolvidos por outros agentes.

Sobre as alteraçóes realizadas pelos moradores e os reparos realizados pela assistência, segundo informaçóes obtidas em respostas ao questionário, verificou-se que as alterações foram realizadas pelos moradores 
em aproximadamente $50 \%$ das moradias, mas os reparos citados na entrevista com o profissional de assistência técnica não encontram relação com problemas decorrentes das alteraçôes na moradia. De acordo com esse profissional, quando alteraçóes eram detectadas pelo serviço da assistência técnica, o morador perdia a garantia e os reparos não eram realizados. Assim, observa-se que as alteraçóes realizadas pelo morador dentro do prazo de garantia podem prejudicar o registro real dos problemas que poderiam ser resolvidos pela assistência técnica.

Sobre o funcionamento das instalaçóes hidráulicas e os reparos da assistência técnica, constatou-se que houve várias declaraçóes de problemas feitas pelos moradores que podem estar relacionados às instalaçôes hidráulicas (vazamentos, infiltraçôes, etc.), e o profissional responsável pela assistência técnica confirma a realização de vários reparos em tais instalaçôes, incluindo obras que necessitaram a abertura de paredes.

A partir de dados sobre a manutençáo da casa e o conhecimento sobre o serviço de assistência, verificou-se que a maioria dos moradores declarou que náo faz manutençôes na casa - o que poderia implicar em maior necessidade de reparos futuros, agravados pela baixa quantidade de pessoas que leu o manual e, portanto, desconhece a necessidade de realizar a manutenção ou mesmo a existência do serviço de assistência técnica.

Sobre os problemas dos principais subsistemas declarados pelos moradores em relação ao serviço de assistência técnica e aos problemas resolvidos por outros agentes, foi possível perceber que as esquadrias (portas e janelas), os pisos e paredes, os revestimentos/acabamentos e as instalaçóes hidráulicas foram os elementos que mais apresentaram problemas. No entanto, isso não é devidamente confirmado pela assistência técnica, além daqueles relacionados às instalaçôes hidrossanitárias.

A insatisfação com o atendimento do serviço de assistência técnica manifestada pelos moradores pode ser compreendida, por um lado, pela tramitação do processo, que tinha a prefeitura como intermediária, conforme descrito pelo responsável pela assistência técnica. Por outro lado, pode também haver a questão da perda do direito à garantia, devido às intervençôes realizadas pelos moradores, que deixaram de ser atendidos, gerando também insatisfação. 


\section{Considerações Finais}

A satisfação das necessidades dos usuários deve ser central nos programas habitacionais e deve ser igualmente considerada em empreendimentos construídos com sistemas construtivos inovadores. Para o Sistema Nacional de Avaliação Técnica de Sistemas Inovadores e Convencionais - SiNAT, a incorporação sistemática de Avaliaçóes Pós-Ocupação (APO) na homologação definitiva de tecnologias deve ser vista como um incremento importante aos testes laboratoriais e ensaios de desempenho técnico já exigidos (FABRICIO; ONO, 2015).

Uma dificuldade inerente à aplicação de Avaliaçôes Pós-Ocupação como instrumento adicional de avaliação de sistemas construtivos inovadores é a impossibilidade de separar perfeitamente o sistema construtivo e o projeto específico da unidade.

A metodologia desenvolvida e aplicada conviveu com essa dificuldade e, de fato, a maioria das questóes levantadas é resultante da interação entre estas duas instâncias: sistema construtivo e projeto da unidade habitacional. Mesmo assim, é possível utilizar os resultados para identificar potenciais problemas ou qualidades oriundas do sistema construtivo e a fim de desenvolver recomendaçóes de projeto para utilização do mesmo sistema construtivo em futuros empreendimentos.

Com relação aos resultados do estudo realizado no caso relatado, a partir da manifestação dos moradores respondentes, verifica-se um bom índice de satisfação geral dos usuários com a residência e com o sistema construtivo empregado no caso estudado. Muitas questóes apontadas, como a necessidade de realizar ampliação (Figuras 11 e 12) ou inadequação de tamanhos de alguns ambientes (cozinha - Figura 16 e área de serviço Figura 18), são oriundas do projeto específico da residência e do modelo de provisão de habitação social, baseado em um projeto padronizado, quase sem diferenciações em função do tamanho, composição ou outras características das famílias. Nesse modelo padronizado, a única customização são as unidades adaptadas para famílias com pessoas com deficiência física.

Quando se considera o perfil heterogêneo das famílias, que apresentam variações expressivas entre o número de residentes na unidade (ver Figura 7) e na composição familiar com ou sem crianças (Figuras 8 e 9), além de um 
menor grau, mas ainda relevante, de variação na escolaridade das famílias atendidas, fica clara a necessidade de modificaçóes no projeto para acomodar as necessidades específicas de cada família atendida. Essa questáo fica mais evidente quando se considera que quase metade dos moradores já realizou alteraçóes na residência (Figura 11) e que 88\% dos moradores planejam realizar alteraçôes na casa (Figura 12).

Com relação a itens diretamente associados ao sistema construtivo, embora possam também ser influenciados pelo projeto, destacam-se problemas relacionados a acabamentos e subsistema complementares, com relato de problemas de piso em $42 \%$ das entrevistas, problemas relacionados às paredes, também em $42 \%$ dos casos, revestimentos/acabamentos (27\%), instalações hidráulicas (21\%), forro/telhado (19\%) e instalações elétricas (13\%). Soma-se a isso, uma grande insatisfação com o processo de assistência técnica, cuja responsabilidade, na percepção dos usuários, é difusa entre construtora, prefeitura municipal e companhia estadual que promoveu o empreendimento.

De fato, a assistência técnica pode ser muito aprimorada nos programas habitacionais, não só para corrigir os problemas encontrados em uso, mas também para sistematizar as ocorrências e investigar as causas com vistas a açóes preventivas, a fim de aprimorar os sistemas construtivos e os futuros projetos habitacionais.

Com relação à metodologia de Avaliação Pós-Ocupação desenvolvida para sistemas construtivos inovadores, destaca-se que ela se mostrou capaz de identificar pontos de satisfação com o sistema construtivo e com o projeto específico e evidenciar problemas recorrentes para serem investigados e avaliados tecnicamente por profissionais especializados e eventualmente por ensaios e inspeçóes, atendendo, portanto, o objetivo proposto no desenvolvimento da metodologia.

Em relação à aplicação do instrumento denominado "Questionário ao Morador" por meio de plataforma digital em substituição aos formulários físicos no processo de coleta de dados, é possível afirmar que tal alternativa foi considerada válida por agilizar e automatizar a tabulação dos dados. E ainda, por meio da plataforma digital, foi possível manter os dados, como horário de início e término, nome do responsável pela aplicação do 
questionário, endereço, coordenadas (não utilizadas), para futuras revisões e memoriais de pesquisa, sendo uma recomendação para replicação do estudo em outros campos.

\section{Referências}

FABRICIO, M.M.; ONO, R. (Orgs.). Avaliaçáo de Desempenho de Tecnologias Construtivas Inovadoras: Manutenção e Percepção do Usuário. Porto Alegre: ANTAC / Caboverde, 2015. v.1, 159 p. DOI: http://dx.doi.org/10.4322/978-85-89478-42-7

ONO, R. et al. Avaliação Pós-Ocupação: pré-teste de instrumentos para verificação do desempenho de empreendimentos habitacionais em sistema construtivos inovadores. Gestão \& Tecnologia de Projetos. São Carlos: Instituto de Arquitetura e Urbanismo da Universidade de São Paulo. v.10. n1. 2015. pp. 64-78. DOI: http://dx.doi.org/10.11606/ gtp.v10i1.88979

ORNSTEIN, S.W.; ONO, R.; OLIVEIRA, F.L. Em busca da qualidade na habitação social no Brasil: instrumentos para a Avaliação Pós-Ocupação (APO) aplicada a sistemas construtivos inovadores. Anais... $4^{\circ}$ CONGRESSO INTERNACIONAL DA HABITAÇÃO NO ESPAÇO LUSÓFONO. Covilhã, Universidade Beira Interior, 2017. p. $49-60$. 
